\title{
FACTORS AFFECTING LOCAL CASSAVA PRODUCTION JALAK TOWO IN KARANGANYAR REGENCY
}

\author{
Maria Vegasari Dian Puspita, Agustono, and Umi Barokah \\ Agribusiness Study program, Agriculture Faculty, Universitas Sebelas Maret Surakarta, \\ Surakarta, Indonesia \\ Correspondence Email: mariavegasari@gmail.com
}

Submitted 16 July 2020; Accepted 17 December 2020

\begin{abstract}
Ubi kayu merupakan salah satu hasil pangan yang menduduki urutan ketiga terbesar setelah padi dan jagung di Indonesia. Provinsi Jawa Tengah menempati urutan ke dua dalam memproduksi ubi kayu di Pulau Jawa. Salah satu kabupaten/kota yang berpotensi untuk dikembangkan dalam berusahatani ubi kayu adalah Kabupaten Karanganyar. Kabupaten Karanganyar memiliki varietas ubi kayu yang dinamakan Jalak Towo. Jalak towo ini memiliki tekstur yang lebih lembut dibandingkan dengan ubi putih lainnya. Penelitian ini bertujuan untuk mengetahui faktor-faktor produksi yang berpengaruh terhadap produksi ubi kayu jalak towo di Kabupaten Karanganyar dan analisi optimasinya. Metode dasar yang digunakan adalah metode deskriptif dan analitis. Lokasi penelitian di Kecamatan Tawangmangu dan Kecamatan Jatiyoso sebagai kecamatan yang menghasilkan ubi kayu jalak towo di Kabupaten Karanganyar. Pengambilan sampel pada penelitian ini menggunakan metode random sampling dengan jumlah total 60 responden yang terdiri dari 30 orang pada setiap lokasinya. Metode analisis data yang digunakan meliputi: analisis fungsi produksi cobb-douglas, analisis varying parameter model dan analisis optimasi. Hasil penelitian ini menunjukkan bahwa faktor-faktor yang berpengaruh pada produksi ubi kayu jalak towo adalah luas lahan, pengalaman, pupuk kandang, pupuk urea, usia petani, dan lokasi. Faktor produksi yang berpengaruh pada produksi ubi kayu dari hasil analisis Varying Parameter Model (VPM) di Kecamatan Tawangmangu adalah luas lahan, pupuk kandang, pupuk urea, usia petani, dan tenaga kerja, sedangkan di Kecamatan Jatiyoso adalah luas lahan dan usia. Hasil analisis optimasi menunjukkan bahwa kombinasi antara faktor faktor-faktor produksi di Kecamatan Tawangmangu dan Kecamatan Jatiyoso belum optimal.
\end{abstract}

Kata kunci: cobb-douglas, jalak towo, optimasi, ubi kayu, varying parameter model

\begin{abstract}
Cassava is one of Indonesia's local food which ranks third largest after paddy and corn. Central Java Province ranks second in producing cassava in Indonesia. One of the regencies / cities that has the potential to be developed in cassava farming is Karanganyar Regency. Karanganyar Regency has a cassava variety called Jalak Towo. Jalak towo has a softer texture compared to other cassava. This study aim were determine the factors of production that affect the production of jalak towo cassava in Karanganyar Regency and its optimization analysis. The basic method used in this research was descriptive and analytical methods. The research location was Tawangmangu Subdistrict and Jatiyoso Subdistrict as sub-districts producing jalak towo cassava in Karanganyar Regency. Sampling in this study using a random sampling method with a total of 60 respondents consisting of 30 people at each location. Data analysis methods used include: cobb-douglas production function analysis, varying model parameter analysis and optimization analysis. The results of this study indicate that the factors that influence the production of jalak towo cassava are land area, experience, manure, urea fertilizer, age of the farmer, and location. Production factors that affect cassava production from the analysis of varying model parameters in Kec. Tawangmangu is the area of land, manure, urea fertilizer, age of the
\end{abstract}


farmer, and labor, while in Kec. Jatiyoso is land area and age. The results of the optimization analysis showed that the combination of the use of production factors in Tawangmangu and Jatiyoso Subistricts ware not optimal.

Keywords: cobb-douglas, jalak towo, optimization, cassava, varying model parameters

\section{INTRODUCTION}

Indonesia is well-known as cassava producer in the world. Indonesia was in the top ten cassava producing countries from 2016-2018 based on FAO data. Indonesia is in sixth place with an average production of $18,477,814.33$ tons. Cassava is one of Indonesia's local food crops and sources of carbohydrates, that is in the third place after rice and maize. This commodity can be an alternative food substance for rice, as well as industrial and export raw materials. Karanganyar Regency is a regency that produces cassava with a productivity of 32.28 tons/ha. Karanganyar Regency grows several types of cassava, such as Jalak Towo. Jalak Towo is a superior local cassava in Karanganyar Regency. Many Jalak Towo are processed into raw materials for making getuk and cheese cassava. The advantages of this Jalak Jowo are that they have a softer texture compared to other eucalyptus cassava and their size is quite large. The weight of the Jalak Towo cassava that are ready to be harvested ranges from $2 \mathrm{~kg}$ to $8 \mathrm{~kg}$.

According to Zaini A., Palupi, N.P., Pujowati, P., Emmawati, A. Emmawati, A (2019), Production is the number of agricultural products obtained within a certain period of time. Agricultural production is the result obtained as a result of the operation of several factors of production at once. Production is affected by various factors such as land area, seeds, fertilizers, pesticides, irrigation systems, labor, and so on. Every farming carried out must have advantages and disadvantages. One way that can be used is to analyze the level of optimization of the farming activities. Optimization is the achievement of a state of the best or the achievement of a solution to a problem that is directed at the maximum and minimum limits. Optimization can be presented in two ways, maximization and minimization. Maximization is the optimization of production by using or allocating certain inputs to get maximum profit. While minimization is the optimization of production to produce a certain level of output by using the least input or cost (Esther, N.D.A., Linawati, L., Mahatma, T., 2013).

Production factors in this research consisted land area, experience, manure, urea fertilizer, farmer age, education, labor and production location. The calculation of the magnitude of the effect of these production factors can help cassava production activities in future. This is because the results of this research can indicate what factors need to be added or reduced. In addition, by finding out the optimization of the production of towo starling cassava, it can increase the production of cassava in the next production because efficient production does not necessarily result in optimal production. This is effected by several factors that can't be added to the use.

This research aimed to determine the effect of the factors of land area, experience, manure, urea fertilizer, farmer age, education, labor and location on the production of Jalak Towo cassava in Karanganyar Regency and to determine the optimization of the use of factors of production of Jalak Towo cassava in Karanganyar Regency.

\section{RESEARCH METHOD}

\section{Basic Method}

Basic method used in this research was descriptive and analytical methods. This method provides an overview, description and explanation of a phenomenon in the object of research (Nazir, 2005). The research results were then processed and analyzed to draw conclusions. The technique of conducting this research was using survey techniques. The 
survey technique was a data collection technique carried out with a sample of a population by compiling a list of questions in the form of a questionnaire that is submitted to the respondent.

The research location method was presented purposively (purposive). It was the method of taking the research area by considering the reasons known from the research area. Determination of the location with the consideration that the selected subdistrict was a sub-district produced jalak towo cassava in Karanganyar Regency. This research was conducted in Tawangmangu and Jatiyoso ditricts in Karanganyar Regency because these locations were the areas where the highest yield of jalak towo cassava was produced.

According to Effendi $\mathrm{S}$ and Tukiran (2014), samples that are classified as big sample and normal distribution is sample with $>30$ cases taken randomly. This research used 60 respondents to obtain a score that represented the entire population of towo starlings in Karanganyar Regency in Tawangmangu and Jatiyoso Districts. The 60 respondents will be divided into 30 respondents in Tawangmangu District and 30 respondents in Jatiyoso District.

\section{Data Analysis Method}

The data analysis methods used in this research were Cobb Douglas production function analysis, Varying Parameter Model (VPM) analysis, and optimization analysis.

\section{Cobb-Douglas Production Function Analysis}

According to Soekartawi (2003), the Cobb-Douglas function is a function or equation involving two or more variables. In which one variable is called the dependent variable, the described variable $(\mathrm{Y})$, and the independent variable, the explaining variable (X). The settlement of the relationship between $\mathrm{Y}$ and $\mathrm{X}$ is usually by means of regression where the variation of $Y$ will be affected by the variation of $\mathrm{X}$. The rules on the regression line also apply in solving the
Cobb Douglas function. The analysis used to determine the relationship between the use of production factors in the form of land area, experience, manure, urea fertilizer, farmer age, education, labor and land location on local cassava production yields using a modified Cobb Douglas production function regression model, with the formula below.

$$
\mathrm{Y}=\mathrm{b}_{0} \cdot \mathrm{X}_{1}{ }^{\mathrm{b} 1} \cdot \mathrm{X}_{2}{ }^{\mathrm{b} 2} \cdot \mathrm{X}_{3}{ }^{\mathrm{b} 3} \cdot \mathrm{X}_{4}{ }^{\mathrm{b} 4} \cdot \mathrm{X}_{5}^{\mathrm{b} 5} \cdot \mathrm{X}_{6}{ }^{\mathrm{b} 6} \cdot \mathrm{X}_{7}^{\mathrm{b} 7} \cdot \mathrm{e}^{\mathrm{D} 1} \cdot \mathrm{e}^{\mathrm{u}}
$$

Converted to natural logarithms:

$$
\mathrm{Ln} Y=b_{0}+b_{1} \ln X_{1}+b_{2} \ln X_{2}+b_{3} \ln X_{3}+
$$$$
\mathrm{b}_{4} \ln \mathrm{X}_{4}+\mathrm{b}_{5} \ln \mathrm{X}_{5}+\mathrm{b}_{6} \ln \mathrm{X}_{6}+\mathrm{b}_{7} \ln \mathrm{X}_{7}+\mathrm{D}_{1}+\mathrm{u}
$$

Where $\mathbf{Y}$ is the yield of cassava production $(\mathrm{kg}) ; \mathbf{X}_{\mathbf{1}}$ is the land area $(\mathrm{m} 2) ; \mathbf{X}_{\mathbf{2}}$ is experience (year); $\mathbf{X}_{\mathbf{3}}$ is manure $(\mathrm{kg}) ; \mathbf{X}_{\mathbf{4}}$ is urea fertilizer $(\mathrm{kg}) ; \mathbf{X}_{5}$ is the age of the farmer (year); $\mathbf{X}_{6}$ is education (year); $\mathbf{X}_{7}$ is labor (HKO); D is the coefficient of the dummy variable consisting of ' 0 ' as the location of the land in Tawangmangu District and ' 1 ' is the location of the land in Jatiyoso District; and $\mathrm{u}$ is the residual.

\section{Analysis of Varying Parameter Model (VPM)}

Rahmawati, A., Agustono, Adi, R.K. (2018) stated that the Varying Parameter Model (VPM) is a method for determining the input-output relation. It is provided that the dummy variables in the Cobb-Douglas model have a significant effect. Dummy variables are used to quantify qualitative variables including gender, race, religion, changes in government policies, and others. Dummy variables are categorical that are considered to have an effect on continuous variables. VPM is a model with dummy elasticity. The model is as follows:

$$
\begin{gathered}
Y=b_{10} X_{1}+b_{11} D_{1} X_{1}+b_{20} X_{2}+b_{21} D_{1} X_{2}+b_{30} X_{3} \\
+b_{31} D_{1} X_{3}+b_{40} X_{4}+b_{41} D_{1} X_{4}+b_{50} X_{5}+ \\
b_{51} D_{1} X_{5}+b_{60} X_{6}+b_{61} D_{1} X_{6}+b_{70} X_{7}+b_{71} D_{1} X_{7}+ \\
b_{0}+e, i \geq 1
\end{gathered}
$$




\section{Optimization Analysis}

The optimization value can be calculated by looking at the Cobb Douglas production function. The Cobb Douglas production function has several useful features such as the marginal product of capital and labor depending on the quantity of both (Salvatore, 2005).

$$
\mathrm{MPPx}_{1}=\frac{\partial \mathrm{Y}}{\partial \mathrm{x}_{1}}=\mathrm{b}_{1} \mathrm{aX}_{1}^{\mathrm{b}_{1}-1} \mathrm{X}_{2}^{\mathrm{b} 2}=\mathrm{b}_{1} \frac{\mathrm{x}_{1}}{\mathrm{Y}}
$$

Information:

$$
\begin{array}{ll}
\text { MPP } & =\text { Marginal Physical Product } \\
\mathrm{b} & =\text { Regression coefficient } \\
\mathrm{X} & =\text { Production factors } \\
\mathrm{Y} & =\text { Production }
\end{array}
$$

The optimization criterion used in this research was the MPP value for each production factor divided by the price giving the same results. It indicated that this farm has reached the optimum combination, but if the ratio is not the same, the farmer can add the use of the production factor with the greatest ratio.

The level of optimization of the use of production inputs is carried out through the Marginal Physical Product (MPP) approach compared to the unit price of variable input (Pxi), in which MPP is the multiplication of the regression coefficient value and the average significance value of the production input variable per unit compared to the product price per unit (in this case, the average price of the product per unit is used). After knowing the MPP of each production factor, it is continued by comparing the MPP with $\mathrm{P}$ or the price of each production factor with the following formula:

$$
\frac{M P P_{X 1}}{P_{X 1}}=\frac{M P P_{X 2}}{P_{X 2}}=\cdots=\frac{M P P_{X n}}{P_{X n}}
$$

\section{RESULT AND DISCUSSION}

\section{Characteristic of Farmer}

Characteristic of farmer in this research was differentiated into six, including the age of the farmer, the level of education, the number of family members of the farmer, farming experience, the area of farming land, and the production of jalak towo cassava.

Based on Table 1, it is known that the average age of farmers in Tawangmangu District was 58 years and in Jatiyoso District was 52 years. Age of farmers had an effectin farming, related to the performance and ability of farmers in decision making. Farmers in productive age tended to be more open and active in seeking information about farm development. The most recent average education taken by respondent farmers was 6 years, that is equivalent to $\mathrm{SD} /$ elementary school.

The average number of farmer family members was 3 people. This resulted in small dependents for the farmer family. The average experience of respondent farmers in Tawangmangu District was 31 years and Jatiyoso District of 26 years. This showed that the respondent farmers have had quite a long experience. This could ease farmers in farming activities.

Farmers as respondents in Tawangmangu District had an average land area of $1,240 \mathrm{~m}^{2}$ with an average production of $1,584 \mathrm{~kg}$.

Table 1. Characteristics of Respondent Farmers in Tawangmangu and Jatiyoso District in 2019

\begin{tabular}{cccc}
\hline No. & Indicators & Tawangmangu & Jatiyoso \\
\hline 1. & Average age of farmers (year) & 58 & 52 \\
2. & Average farmer education (year) & 6 & 6 \\
3. & Average family members (person) & 3 & 3 \\
4. & Average farming experience (year) & 31 & 26 \\
5. & Average land area $\left(\mathrm{m}^{2}\right)$ & 1.240 & $1.396,67$ \\
6. & Average production $(\mathrm{kg})$ & 1.584 & $2.253,33$ \\
\hline
\end{tabular}

Source: Primary Data, 2019 
The average land area in Jatiyoso District was $1,396.67 \mathrm{~m}^{2}$ and the average production was $2,253.33 \mathrm{~kg}$. This showed that Jatiyoso Subdistrict had a larger average area of land and production than Tawangmangu District.

\section{Analysis of the Cobb Douglas Production Function}

According to the results of the analysis of the jalak towo cassava production using the regression model, it can be written in the following equation:

$\operatorname{Ln} \mathrm{Y}=-1,427+0,751 \ln \mathrm{X}_{1}-0,303 \ln \mathrm{X}_{2}+$ $0,280 \ln X_{3}-0,017 \ln X_{4}+0,676 \ln X_{5}+0,209 D_{1}$

The results of the $\mathrm{R}^{2}$ Determination Test analysis showed that the R2 value was 0.821 . It means that $82.1 \%$ of the variation in the yield of jalak towo cassava can be explained by the production factors included in the model. While the remaining $17.9 \%$ was explained by other variables that were not included in the model.

\section{a. F-test}

F-test was used to find out the effect of the use of production factors together on the production of cassava. The F-test was carried out at the $95 \%$ confidence level or a significance value of 0.05 . The results of the F-test can be seen in Table 2 .

The results of statistical calculations in Table 2 showed that the calculated $\mathrm{F}$ value was 29.327 with a significance of $0.000<\alpha(\alpha$ $=0.05)$. This showed that $\mathrm{H} 0$ was rejected and $\mathrm{H} 1$ was accepted. Rejected $\mathrm{H} 0$ indicated that the factors of land area, experience, manure, urea fertilizer, age, education, labor, and land location together affected the production of jalak towo cassava production in Tawangmangu and Jatiyoso Districts. After knowing the effect of the independent variables on the dependent variable, then the t-test was carried out to determine the partial variable relationship.

\section{b. T-test}

The t-test is known as the partial test to test how the effect of each independent variable partially on the dependent variable. This test can be conducted by comparing the $\mathrm{t}$-count with the t-table or by looking at the significance column for each t-count, the $t$ test process is identical to the $\mathrm{F}$ test. The $\mathrm{t}$ test is carried out at a $95 \%$ confidence level or a significance value of 0.05 . The results of the $t$ test are presented in Table 3.

Table 2. Simultaneous Significance Test Results (Test F)

\begin{tabular}{ccccccc}
\hline & Model & Sum of Squares & df & Mean Square & F & Sig. \\
\hline 1 & Regression & 14,273 & 8 & 1,784 & 29,327 & $0,000^{\mathrm{b}}$ \\
& Residual & 3,103 & 51 & 0,061 & & \\
& Total & 17,375 & 59 & & & \\
\hline
\end{tabular}

Source: Primary Data, 2019

Table 3. Results of the Analysis of the Significance of Individual Parameters (t Test)

\begin{tabular}{cccc}
\hline Variable & $\mathrm{B}$ & $\mathrm{t}$ & Sig. \\
\hline Land area & 0,751 & 3,982 & $0,000^{* * *}$ \\
Experience & $-0,303$ & $-2,202$ & $0,032^{* *} \mathrm{~s}$ \\
Manure & 0,280 & 2,089 & $0,042^{* *}$ \\
Urea fertilizer & $-0,017$ & $-2,354$ & $0,022^{* *}$ \\
Age & 0,676 & 2,403 & $0,020^{* *}$ \\
Education & $-0,019$ & $-1,230$ & $0,224^{\mathrm{ns}}$ \\
Labor & $-0,036$ & $-0,151$ & $0,880^{\mathrm{ns}}$ \\
Location & 0,209 & 2,564 & $0,013^{* *}$ \\
\hline
\end{tabular}

Source: Primary Data, 2019 
The results of the $t$ test indicated that the variables that significantly affected the production of jalak towo were land area, experience, manure, urea fertilizer, age, and location. Meanwhile, the variables that did not have a significant effect were education and labor.

The land area in this research had a significance of $0.000<\alpha(0.05)$. This was in accordance with Supriyatno (2008) that land area affects the production of cassava. Each additional land use of $1 \%$ would increase the production of jalak towo by $0.751 \%$. The more land is used, the more cassava plants will be produced.

Farming experience was a factor that significantly affected the cultivation of jalak towo cassava. The significance value was $0.032<\alpha(0.05)$. This was in line with the results of Yoko's (2014) research showing that farmers' experiences have an influence on production. The regression coefficient value of the experience factor was -0.303 . It means that the addition of farming experience by $1 \%$ could reduce the production of jalak towo by $0.303 \%$. Farmers with longer experience were not necessarily able to increase cassava production. It could also be concluded that the lack of experience of farmers in farming was not an obstacle to increasing the production of towo starling cassava. Most of the farmers with more than 20 years of experience prefer to do farming activities that they have been doing for a long time and do not adapt to new existing technologies.

The use of manure factors has a positive effect on the production of towo starling with a significance of $0.042<\alpha$ (0.05). The regression coefficient value of the manure variable was 0.28 .

It means that the addition of $1 \%$ manure can increase the production of jalak towo by $0.28 \%$. This was in line with the research of Yasa (2017) and Sa'diyah (2011) that the application of fertilizer had an effect on production.

The urea fertilizer variable in this research a negative effect on the production of jalak towo cassava. The value of the regression coefficient iwas-0.017. Each additional $1 \%$ use of urea fertilizer would reduce cassava production by $0.017 \%$. This is supported by research by Fadwiwati (2013) which stated that the urea fertilizer factor affects production. However, the use of excessive urea fertilizer can cause plants to wither easily and reduce nutrients in the soil. Thus, it results a decrease in production.

The farmer's age had an effect on the farmer's ability to respond to new things in farming. This research showed that increasing the age of the farmers by $1 \%$ could increase the production of cassava by $0.676 \%$. This was supported by research by Olubunmi (2018) stating that age affected the productivity of cassava.

Based on the results of regression analysis, the length of education taken by farmers had a significance value of $0.200>\alpha$ (0.05), thus, it did not have a significant effect. It means that the length of education taken by farmers dis not significantly affect the production of jalak towo cassava. This was in accordance with Susanti's (2016) research that the length of education of farmers dis not affect production. Respondent farmers in this research had an average education only up to elementary school. It had relation to the production of cassava produced.

The labor factor had a significance value of 0.877 that was greater than $\alpha(\alpha=$ $0.05)$, thus, it dis not have a significant effect. The addition of manpower dis not have any effect on cassava production. It was affected by the addition of labor not followed by an expansion of the land used. Hence, the large number of workers used did not guarantee an increase in production. In accordance with the research of Supriyatno (2008), labor/worker does not affect production. The addition of labor did not have any effect on cassava production affected by the addition of labor not followed by expansion of the land used.

This research used a dummy variable in the form of land location. The land location factor had a significance of $0.013<\alpha(0.05)$. 
Table 4. Results of the Varying Parameter Model (VPN) Analysis

\begin{tabular}{clrr}
\hline No & \multicolumn{1}{c}{ Variable } & Tawangmangu & Jatiyoso \\
\hline 1 & Land area $\left(\mathrm{X}_{1}\right)$ & 2,277 & 0,683 \\
& & $(0,000)^{* *}$ & $(0,088)^{*}$ \\
2 & Experience $\left(\mathrm{X}_{2}\right)$ & $-15,024$ & $-24,999$ \\
& & $(0,389)^{\mathrm{ns}}$ & $(0,116)^{\mathrm{ns}}$ \\
3 & Manure $\left(\mathrm{X}_{3}\right)$ & 1,896 & 0,478 \\
& & $(0,000)^{* *}$ & $(0,385)^{\mathrm{ns}}$ \\
4 & Urea fertilizer $\left(\mathrm{X}_{4}\right)$ & $-12,237$ & $-5,083$ \\
& & $(0,015)^{* *}$ & $(0,408)^{\mathrm{ns}}$ \\
5 & Age $\left(\mathrm{X}_{5}\right)$ & 28,446 & 28,604 \\
& & $(0,030)^{* *}$ & $(0,065)^{*}$ \\
6 & Education $\left(\mathrm{X}_{6}\right)$ & 60,780 & 5,387 \\
& & $(0,189)^{\mathrm{ns}}$ & $(0,903)^{\mathrm{ns}}$ \\
7 & Labor $\left(\mathrm{X}_{7}\right)$ & $-75,969$ & 11,649 \\
& & $(0,000)^{* *}$ & $(0,381)^{\mathrm{ns}}$ \\
8 & Constant & $-1018,648$ & $-1018,648$ \\
& & $(0,082)$ & $(0,082)$ \\
\hline
\end{tabular}

Source: Primary Data, 2019

This showed that land location had a significant effect on cassava production. This was in accordance with the research of Sa'diyah (2011) that location affects production. Several things that distinguished these two locations included the larger population in Tawangmangu District. The average land area used for jalak towo farming showed that Jatiyoso District had a wider area than Tawangmangu District. In addition, cassava production is also affected by rainfall conditions. Tawangmangu District has an average rainfall of $156 \mathrm{~mm} / \mathrm{month}$ and Jatiyoso District is $258.75 \mathrm{~mm} / \mathrm{month}$.

\section{Analysis of Varying Parameter Mode (VPM)}

VPM analysis is an advanced analysis of Cobb Douglas regression analysis. In the Cobb Douglas regression analysis, it can be seen that the dummy variable was significant for cassava production. It means that there are differences affected by land location. Analysis of Varying Parameter Model (VPM) was conducted to determine what factor affecting the production of cassava in each district that was the research location.

Farmers' land area in Tawangmangu and Jatiyoso was significant for the production of jalak towo with a significance value of 0.000 and 0.088 . It was smaller than $\alpha(\alpha=0.05$ and 0.1$)$. The more land was used, the more cassava production would be produced.

The regression coefficient of the experience factor in Tawangmangu and Jatiyoso was 0.389 and 0.116 bigger than $\alpha(\alpha$ $=0.05$ and 0.1 ). The experience factor did not have a significant effect on the production of jalak towo cassava in Tawangmangu and Jatiyoso. Based on the results of the research, farmers in the two districts had on average more than 25 years of experience. This showed that experience couldn't be used as a reference for the success of a farm.

The use of manure in Tawangmangu was significant for the production of jalak towo cassava with a significance of $0.000<\alpha$ $=0.05$. While in Jatiyoso, the significance was 0.385 . Thus, there was no significant effect. The regression coefficient value in Tawangmangu District was 1,896 . It means that the addition of $1 \%$ of manure would increase the production of jalak towo cassava by $1.896 \%$. This was because manure is very useful for fertilizing and nourishing the soil. Hence, it was necessary to add manure to increase the production of jalak towo cassava. 
Table 5. Optimization Calculation Results in Tawangmangu District and Jatiyoso District

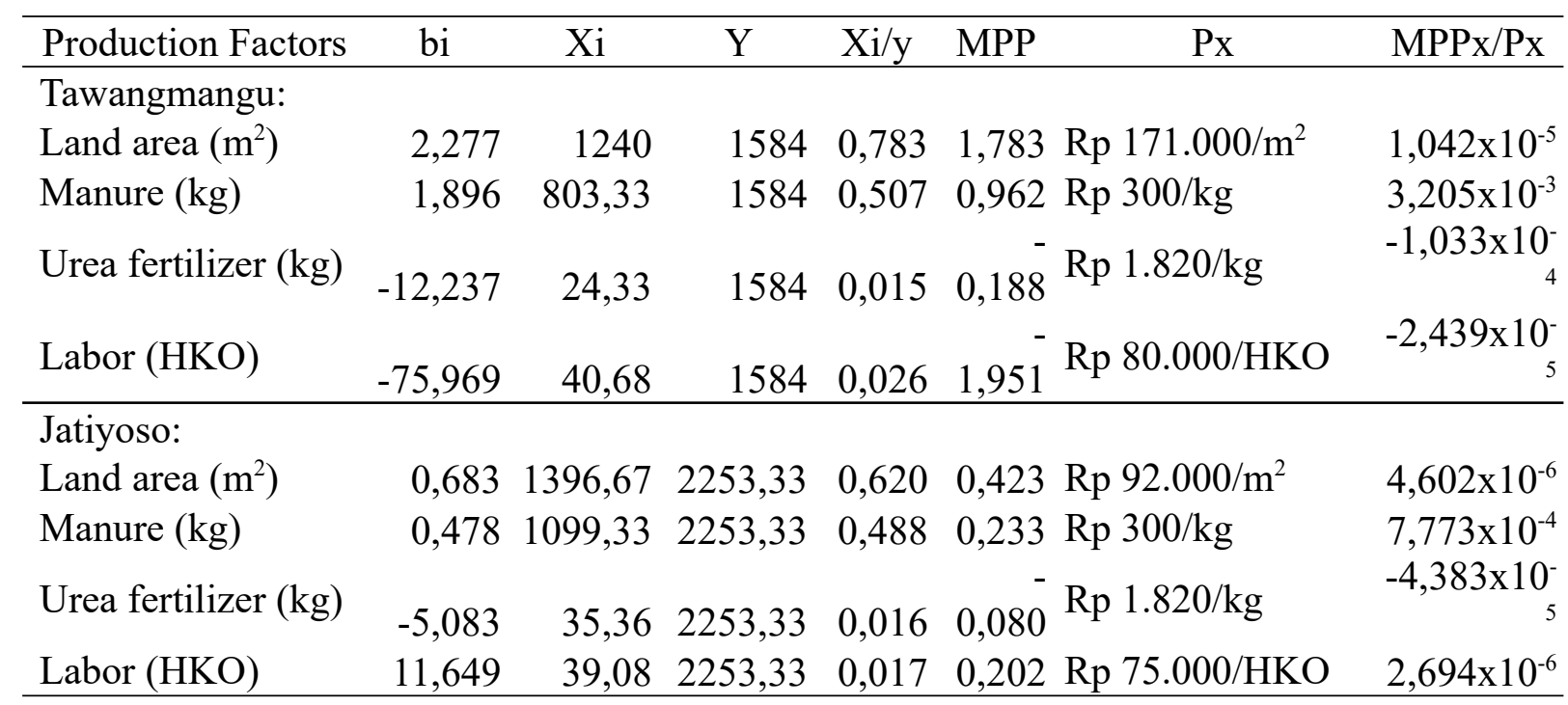

Source: Primary Data, 2019

The use of fertilizer in Jatiyoso District had reached a saturation point so that the addition of manure couldn't increase the production of cassava.

The regression results showed that urea fertilizer was significant for the production of jalak towo cassava in Tawangmangu with a significance of 0.01 . While the urea fertilizer factor was not significant in Jatiyoso District. The regression coefficient value of urea in Tawangmangu District was -12.237 . This showed that the addition of $1 \%$ urea fertilizer used in the cultivation of jalak towo would reduce the production of cassava by $12.237 \%$. The content of urea fertilizer used excessively could actually cause cassava production to decrease and does not have any effect on plants. As in Jatiyoso District, the area is no longer able to increase cassava production by adding urea fertilizer.

The age variable in Tawangmangu and Jatiyoso had a significance level of 0.030 and 0.065 smaller than $\alpha(\alpha=0.05$ and 0.1$)$. It means that the age factor had a significant effect on the production of jalak towo. The age of farmers who were good at farming was the productive age, because their catching power and insight were still able to keep up with existing technological developments.
Farmers with unproductive age tended to choose to farm in easy and traditional ways.

The regression coefficient value of the education factor in Tawangmangu and Jatiyoso was 0.189 and 0.903 bigger than $\alpha(\alpha$ $=0.05$ and 0.1 ).

It means that the educational factor did not significantly affect the production of towo starling cassava. This figure shows that farmers with low or high levels of education were not necessarily able to increase cassava production because they had a broader mindset in farming.

The use of worker in Tawangmangu was significant for cassava production with a significance value of $0.000<\alpha(0.05)$, while in Jatiyoso, it was not significant with the sig value of 0.381 . The regression coefficient value in Tawangmangu District was -75.969. The addition of worker of $1 \%$ would cause a decrease in cassava production by $75.969 \%$. Increased production of jalak towo cassava in Tawangmangu District could be presented if the use of labor was limited. This showed that using many workers would actually make farming activities ineffective. This means that the use of the number of workers with a high number of working days and hours of work does not guarantee an increase in the production of jalak towo cassava. 


\section{Optimization Analysis}

Optimization analysis is the achievement of a best state. It is the achievement of a solution to a problem that is directed at the maximum and minimum limits. The level of optimization of the use of production inputs is carried out through the Marginal Psychological Product (MPP) approach compared to the unit price of variable input (Pxi). The results of the optimization analysis are presented in Table 5.

The use of production factors is considered to be optimal if the ratio of MPPx 1 / Px1 is the same as MPPx 2 / Px2 and other production factors. The MPP value for each factor of production divided by the price gave the same results. It indicated that this farm had reached the optimum combination, yet, if the ratio is not the same, the farmer could add the use of the production factor with the greatest ratio.

Based on the calculation of the optimization value, it showed that the combination of the use of production factors in this research was not optimal. It can be seen from the comparison of each different production factor. Based on the optimization criteria, to achieve optimal business, it is necessary to add to the production factor with the greatest ratio, namely manure. The absence of definite guidelines regarding a good combination of one factor with another is one of the causes for this not optimal farming.

The use of effective land is not necessarily optimal. Because in order to achieve, it is necessary to increase the land area which is inversely proportional to current agricultural conditions. The land was getting narrower because it is used for residential and industrial purposes so that the maximum yield of towo starling cassava can be done by maximizing the land that is currently owned. Manure used has also not reached optimal because the amount of fertilizer used in farming is not accurate. Different land conditions also caused different needs for manure. Thus, it is necessary to add manure to achieve better conditions in producing jalak towo cassava. While the use of urea fertilizer needed more attention because it can reduce production, thus, the use of urea fertilizer is better reduced or replaced with other fertilizers such as TSP and NPK. The use of labor in the form of HKO (Person Work Day) for each land is different, thus, it is necessary to consider the amount of labor and time needed in farming in order to increase the production of towo client cassava.

\section{CONCLUSIONS}

The factors of land area, experience, manure, urea fertilizer, age of farmers, and location have a significant effect on the production of jalak towo cassava in Karanganyar Regency. Based on the VPM analysis test in Tawangmangu District, it shows that the factors of land area, manure, urea fertilizer, farmer age, and labor have a significant effect on the production of jalak towo cassava. Meanwhile, in Jatiyoso Subdistrict, the factors of land area and age have a significant effect on the production of jalak towo in Karanganyar Regency. The optimization analysis conducted shows that the combination of the factors of land area, manure, urea fertilizer, and labor in Tawangmangu and Jatiyoso Districts is not optimal.

Suggestions that can be given are as follows: 1) Farmers in Tawangmangu District can increase the production of jalak towo cassava by optimizing arable land, paying more attention to the use of fertilizers in farming, and paying attention to the performance of the workforce used. 2) Farmers in Jatiyoso District can increase production of towo starling cassava by maximizing the cultivated land they own and empowering farmers at productive age.

\section{REFERENCES}

Effendi, S. and Tukiran. 2014. Metode Penelitian Survei. Jakarta. LP3ES. 
Esther, N. D. A., L. Linawati, and T. Mahatma. 2013. Penerapan model linear goal programming untuk optimasi perencanaan produksi. Proceeding Seminar Nasional Sains dan Pendidikan Sains VII: 464-471.

Fadwiwati, A. Y. and A. G. Tahir. 2013. Analisis faktor-faktor yang mempengaruhi produksi dan pendapatan usahatani jagung di Provinsi Gorontalo. Jurnal Pengkajian dan Pengembangan Teknologi Pertanian 16(2): 92-101.

Nazir, M. 2005. Metode Penelitian. Jakarta. Ghalia Indonesia.

Olubunmi, L. B., J. O. Ifeoluwa, A. A. B. Taofeek, and J. A. Osagie. 2018. Effect of social capital on productivity of cassava farmers in Ogun State, Nigeria. Journal of Agricultural Sciences 63(1): 99-112.

Rahmawati, A., Agustono, and R. K. Adi. 2018. Usahatani organik padi putih dan padi hitam: pendekatan pendapatan, fungsi produksi CobbDouglas dan VPM. Caraka Tani: Journal of Sustainable Agriculture 33(1): 8-18.

Sa'diyah, A. A. and R. E. Muljawan. 2011. Kajian ekonomi usahatani kubis Di Kecamatan Sukapura Kabupaten Probolinggo. Jurnal Buana Sains 11(2): 103-108.

Salvatore, D. 2005. Managerial Economics: dalam Perekonomian Global edisi 5. Jakarta. Salemba Empat.

Soekartawi. 2003. Teori Ekonomi Produksi dengan Pokok Bahasan Analisis CobbDouglas. Jakarta. Raja Grafindo Persada.

Sugiyono. 2013. Metode Penelitian Kuantitatif, Kualitatif, dan R\&D. Bandung. Alfabeta.
Supriyatno, Pujiharjo, and S. Budiningsih. 2008. Analisis efisiensi alokatif penggunaan faktor produksi usahatani ubi kayu (Manihot esculenta) di Desa Punggelan Kecamatan Punggelan Kabupaten Banjarnegara. Jurnal AGRITECH 10(1): 30-40.

Susanti, D., N. H. Listiana, and T. Widayat. 2016. pengaruh umur petani, tingkat pendidikan dan luas lahan terhadap hasil produksi tanaman sembung. Jurnal Tumbuhan Obat Indonesia 9(2): 75-82.

Yasa, I. N. A. and Hadayani. 2017. Analisis produksi dan pendapatan usahatani padi sawah di Desa Bonemarawa Kecamatan Riopakava, Kabupaten Donggala. E-Journal Agrotekbis 5(1): 111-118.

Yoko, B., Y. Syaukat, and A. Fariyanti. 2014. Analisis efisiensi usahatani padi di Kabupaten Lampung Tengah. Jurnal Agribisnis Indonesia 2(2): 127-140.

Zaini, A., N. P. Palupi, P. Pujowati, and A. Emmawati. 2019. Nilai Tambah dan Daya Saing Produk Unggulan di Kutai Barat. Yogyakarta. Deepublish Publisher. 